\title{
Antimicrobial activity of medicinal plants used for urinary tract infections in pastoralist community in Ethiopia
}

\author{
Eshetu Gadisa ${ }^{1 *}$ (D) and Elazar Tadesse ${ }^{2}$
}

\begin{abstract}
Background: Medicinal plants have wide medicament application used to prevent and management of many ailments. These plants are used for primary health care in pastoralist communities who are deprived of modern medical care. They possess extensive therapeutics bioactive coupled with varied chemical structures. However, scientific validation of efficacy and safety of plants used to treat the urinary tract infections haven't been fully exploited. The aim of this study was to evaluate antimicrobial activity and screening phytochemicals of medicinal plants used to treat urinary tract infections.
\end{abstract}

Methods: In-vitro experimental study was carried out to evaluate the antimicrobial effect and screening phytochemical of Rumex abyssinicus, Cucumis pustulatus, Discopodium penninervium, Lippia adoensis, Euphorbia depauperata, and Cirsium englerianum. Against drug resistance microbes. $80 \%$ methanol was used for extraction of the plant parts. The susceptibility tests were investigated using disc diffusion and broth micro-dilution methods.

Results: The majority of tested extracts showed antimicrobial activity on two or more drug-resistant bacteria with MIC value $(1.0-128.0 \mathrm{\mu g} / \mathrm{ml})$ and 9-27 mm inhibition zone in diameter. Extracts obtained from C.englerianum and E. depauperate showed more potent antibacterial activity on MRSA and Enterococcus faecalis with IZ 25 and $27 \mathrm{~mm}$ respectively. E. coli and K. pneumoniae were inhibited by those extracts with $I Z$ ranging $9-25 \mathrm{~mm}$ and $11-27 \mathrm{~mm}$ respectively. Efaecalis and $K$. pneumoniae were more susceptible bacteria to the respective extracts. $R$. abyssinicus showed promising antifungal effect with had $21 \mathrm{~mm} \mathrm{IZ}$ and MIC range 16-32 $\mathrm{mg} / \mathrm{ml}$ on C.albicans. Alkaloids, flavonoids, phenolic and terpenoid were common phytochemical characterized in majority of screened plants.

Conclusion: Tested extracts exhibited significant antibacterial and antifungal activity. Hence, further structural elucidation of bioactive that inhibited the growth of microbes aforementioned plants may be used as precursors for the synthesis of new antibiotics in the future.

Keywords: Cirsium englerianum, Cucumis pustulatus, Discopodium penninervium, Multidrug resistance

\footnotetext{
* Correspondence: gadisa.eshetu@kmu.edu.et; gadisaeshetu@gmail.com

'Department of Medical Laboratory Science, Menelik Medical and Health

Science College, Kotebe Metropolitan University, P.O. Box 3268, Addis Ababa, Ethiopia

Full list of author information is available at the end of the article
}

(C) The Author(s). 2021 Open Access This article is licensed under a Creative Commons Attribution 4.0 International License, which permits use, sharing, adaptation, distribution and reproduction in any medium or format, as long as you give appropriate credit to the original author(s) and the source, provide a link to the Creative Commons licence, and indicate if changes were made. The images or other third party material in this article are included in the article's Creative Commons licence, unless indicated otherwise in a credit line to the material. If material is not included in the article's Creative Commons licence and your intended use is not permitted by statutory regulation or exceeds the permitted use, you will need to obtain permission directly from the copyright holder. To view a copy of this licence, visit http://creativecommons.org/licenses/by/4.0/ The Creative Commons Public Domain Dedication waiver (http://creativecommons.org/publicdomain/zero/1.0/) applies to the data made available in this article, unless otherwise stated in a credit line to the data. 


\section{Background}

Over the past several decades urinary tract infection is one of the most common infections. It is mostly caused by gram-negative bacteria namely E.coli $P$. aeruginosa and P.neumoniae [1]. There are also urinary tract infection (UTI) caused from S. aureus and E. faecalis and C. albicans in immunocompromised patients and pregnant women [2]. On the top of this, emerging and re-emerging of MRSA, extended-spectrum $\beta$-lactamases producing organisms (ESBL), vancomycin-resistant enterococci (VRE), and the carbapenem-resistant organisms (CRE/CRP) is a global public health challenge and imposed socioeconomic crisis worldwide [3, 4]. WHO report showed overuse and misuse of available antibiotics and lack of discovery of the new antimicrobials drug by the pharmaceutical industry make the crisis more sever and life threaten condition UTI infected patients [5].

On the other hand, many resistance genes/ gene products are speed in bacteria population through efflux, hyper-mutability and plasmid addiction. Such factors attributed for compromised all or majority of the drugs belonging to a given therapeutic [6]. As a result, urinary tract infections caused with resistant organisms have higher morbidity and mortality, are costlier to treat, result in longer hospital stays and place a greater burden on health systems than infections caused by susceptible organisms. Many studies shown that in United States, at least 2 million people acquire serious infections with bacteria that are resistant to one or more of the antibiotics used for the treatment of infections [7]. The total economic cost of antibiotic resistance was estimated as high as $\$ 20$ billion in direct healthcare and \$35 billion in lost productivity per year. If there were no successful efforts to cure them or no new drugs to combat them, the number of deaths per year would be ten million and the cost would increase up to $\$ 100$ trillion by 2050 [8]. So, searching for innovative antibiotics from natural products should be ultimately an important segment of modern medicine to overcome the various socioeconomic and health impacts caused by multidrug resistant microbes [9].

Searching of medicinal plants used as alternatives or complementary treatment of emerging and re-emerging of multidrug resistance bacteria is undergoing a revitalization because it is available, accessible, affordable and acceptable to the local population [10]. According to WHO report, medicinal plants can potentially meet communities needs and improve access to safe, quality and culturally sensitive primary health care. Which in turn, they can make a significant contribution to essential health services in the prevention and management of communicable diseases caused by drug resistance bacteria [11]. Many studies have shown that each medicinal plant has many phytochemical compounds namely coumarins, flavonoids, phenolic, alkaloids, terpenoids, tannins, essential oils, lectin, polypeptides, and polyacetylenes. The presence of these bioactive compounds can show bactericidal or bacteriostatic effects on multidrug resistance pathogen bacteria and also as precursor for develop antibiotics for treating infectious agents, mainly from urinary tract infections causing bacteria [12-14].

Likewise, antibacterial potent of crude extract obtained from Bidens sulphurea, Bidens pilosa, and Tanacetum vulgare demonstrated antibacterial action on $S$. aureus, E. faecalis, E.coli, and P. aeruginosa isolated from UTI patients and standard bacterial strains ranged from 7.81$125 \mathrm{mg} / \mathrm{l}$ and the $\mathrm{MBC}$ values ranged from 7.81-500 $\mathrm{mg} / \mathrm{l}$ [15]. Calotropis gigantean has shown no antibacterial and antifungal activities for n-hexane fractions against pathogenic microbes; however, its ethyl-acetate fractions how potential inhibitory effects on all tested bacteria and fungi except T.rubrum [16].

Another study conducted on the organic extracts of Phragmanthera capitat had comparative antimicrobial activities against ten pathogen bacteria with a MIC of $1.25-5 \mathrm{mg} / \mathrm{ml}$ and $\mathrm{MBC}$ of $2.5-10 \mathrm{mg} / \mathrm{ml}$ and fungi species with a MIC of less than 0.3125 to $1.25 \mathrm{mg} / \mathrm{ml}$ [17]. Likewise, the aqueous extracts of Carum copticum, and Albizia adianthifolia showed significant antibacterial effect against multidrug resistance gram negative human pathogen bacteria such as E.coli, Pseudomonas, K. pneumonia, Salmonella and Proteus species [18, 19]. Several aqueous and hydro-alcoholic extracts obtained from different plants were screened for their antibacterial effects against human pathogenic bacteria and demonstrated remarkable antibacterial effects on multidrug resistant bacteria including MRSA and ESBL producing bacteria [2024]. Moreover, a significant number of plants exhibited a broad antibiotic spectrum against multidrug resistant bacteria, which could help to control the problem of the global threat imposed by infections due to multidrug resistant bacteria $[25,26]$.

It has been pointed out that chemical synthesis and the search for natural products from living organisms (marine and higher plants) are the two major sources of new bioactive compounds. However, less than $1 \%$ of plants were isolated and characterized for their secondary metabolites and used for pharmacological utilization [27, 28]. Traditional medicinal plants are the most valuable sources of new bioactive chemical entities due to their biodiversity coupled with the chemical diversity found within each species [29-33]. In line with this, C.englerianum, E.depauperata, $L$ adoensis, D.penninervium, C.pustulatus and R.abyssinicus are TMPs used by communities for treatment of different infectious agents. Yet, they haven't been thoroughly examined for their antimicrobial potential and phytochemical entities as therapeutic agents for multidrug resistant bacteria and human pathogen fungi. 


\section{Methods}

\section{Study area and design}

Study area

This study was conducted in the Seweyna Woreda, Bale Zone. This Woreda is located $437 \mathrm{~km}$ away from Robe (Zonal Town) in the Northern east direction and $750 \mathrm{~km}$ from the capital city, Addis Ababa. An elevation extends from 400 to $1850 \mathrm{~m}$ above sea level and is located at coordinates latitude $7^{\circ} 19^{\prime} 60.00^{\prime \prime} \mathrm{N}$ and longitude $41^{\circ} 19^{\prime}$ $60.00 "$ E. major rivers include the Mekenisa, Dare, Manduba, and Kurkura. According to the national land survey showed arable or cultivable (24.4\%), pasture (46.3\%), forest or heavy vegetation, and forest $(24.1 \%)$ of the land. This district is the remotest area with no infrastructure (transport, hospital, and power supplies). Since there was only one health center in the Woreda, the residents depend on traditional knowledge of medicinal plants to treat human ailments such as skin diseases, diabetes, UTI, hepatitis, sexual transmitted infection, cancer, hypertension, impotence, and contraceptive.

\section{Study design and period}

In vitro, an experimental study was carried out to evaluate the antimicrobial effect and screening phytochemical of C.englerianum, E.depauperata, L adoensis, D.penninervium, C.pustulatus and R.abyssinicus against clinically isolated multidrug-resistant bacteria and their reference strains, and pathogen fungi at KMU, MMHSC, Core Laboratory from January to April, 2020.

\section{Medicinal plants selection criteria}

Nowadays, communities are deprived of modern medical care and depend on the traditional medicinal plants to treat many human and animals' ailments such as skin diseases, diabetes, urinary tract infection, hepatitis, sexually transmitted diseases, cancer, hypertension, sexual impotence, and contraceptive. Of which, C.englerianum, E.depauperata, L adoensis, D.penninervium, C.pustulatus and R.abyssinicus are commonly used to treat bacterial infection such as eczema, gonorrhea, syphilis, pneumonia, scabies, skin infection, and superficial mycosis.

\section{Plant collection and extraction}

The leaf, bark, or root parts of C.englerianum, E.depauperata, L adoensis, D.penninervium, C.pustulatus and R.abyssinicus was collected and screened for their antibacterial and fungi and phytochemical. Authentication of this plant sample was carried out and deposited at the National Herbarium, Department of Biology, Faculty of Natural Science and computational Science, Addis Ababa University. The fresh parts of the plant were collected and washed thoroughly under running tap water and dried in dark shaded areas. The air-dried plant materials $(4 \mathrm{~kg}$ each) was powdered and extracted at room temperature with $80 \%$ methanol and distilled water. Triplicate of $200 \mathrm{~g}$ portions of the dried powdered plant was soaked separately in $1000 \mathrm{ml}$ of distilled water, or methanol for 3 days with frequent agitation and the resulting liquid was filtered using Whatman No.1 filter paper (Whatman Ltd., England). Extraction was repeated seven times and the filtrates of all portions were combined in one vessel. The methanol was removed by evaporation using Rota vapor at $40{ }^{\circ} \mathrm{C}$. After the removal of the organic solvent, the aqueous residue was placed in lyophilizer until non-polar solvents removed and dried the extracts. The resulting dried mass packed into a glass vial and stored in a desiccator over silica gel until use $[13,32]$.

\section{Sterility test of extracts}

Each extract of methanol and aqueous was tested for the growth of bacteria. This was carried out by inoculating $0.5 \mathrm{ml}$ of each of them on sterile Mueller Hinton Agar and incubated at $37^{\circ} \mathrm{C}$ for $18-24 \mathrm{~h}$. The plates were observed for growth. No growth in the extracts after incubation indicated that they were sterile and evaluated for antibacterial activity as described by CLSI guideline [32].

\section{Culture media and multidrug bacteria Culture media}

Nutrient agar, TSY broth, MacConkey, Muller Hinton agar, Muller Hinton Broth, blood agar, mannitol salt agar, chocolate agar and biochemical reagents for bacteria and sabouraud dextrose agar for fungi were obtained from the Departments of Medical Laboratory Science, Bacteriology Unit.

\section{Test organisms}

The reference bacterial species of E. coli (ATCC25922), K. pneumoniae (ATCC700603), Enterococcus faecalis (ATCC 29212) and Staphylococcus aureus (ATCC 25923) and their MDR strains, and fungi i.e. Candida albicans reference (ATCC 10535 and those obtained from sample) were used for this study [32].

\section{Modern antibiotics}

Currently available antibiotics; ciprofloxacin $(5 \mu \mathrm{g})$, gentamycin $(10 \mu \mathrm{g})$, cephalotaxon $(30 \mu \mathrm{g})$, cefotaxime $(5 \mu \mathrm{g})$, ceftazidime $(10 \mu \mathrm{g})$, cefoxitin $(30 \mu \mathrm{g})$, ceftriaxone $(30 \mu \mathrm{g})$, amikacin $(30 \mu \mathrm{g})$, cefuroxime $(5 \mu \mathrm{g})$, ceftriaxone $(30 \mu \mathrm{g})$, cloxacillin $(5 \mu \mathrm{g})$, and augmentin $(30 \mu \mathrm{g})$ were used to test for bacteria and ketoconazole $(20 \mu \mathrm{g})$ for C. albicans as stated in the CLSI guideline [32].

\section{Screening for multidrug resistant bacteria}

Multidrug resistant gram negative and gram-positive bacteria were isolated from different samples (urine, throat swab and blood). All bacterial cultures were first 
grown on $5 \%$ blood agar plates at $37^{\circ} \mathrm{C}$ for $18-24 \mathrm{hrs}$ prior to inoculation onto the MHA. Few colonies (3-5) of similar morphology of the respective bacteria were transferred with a sterile inoculating loop to a liquid medium until adequate growth of turbidity with McFarland in 0.5. Then the bacterial suspension was streaked on MHA plates using a sterile swab in such a way as to ensure thorough coverage of the plates and a uniform thick lawn of growth following incubation. The susceptibilities of clinical isolates were tested by using the MHA contains a range of antimicrobial agents. Dilutions of overnight broth cultures were inoculated onto antibiotic containing plates to yield final inoculums of approximately $10^{6} \mathrm{CFU}$ per spot for Enterobacteriaceae. Selected multidrug resistant $K$. pneumoniae and E. coli were screened for their resistant for more than two different classes of antibiotics following the disk diffusion method as CLSI guideline [13, 31, 32].

\section{Determination of MIC and MBC values}

After preliminary screening of plants for their antimicrobial activity, those revealed potent antimicrobial effects were further tested to determine MIC and MBC against multidrug resistant gram negative, and gram-positive species. It was determined by MHB broth micro-dilution method. Each 96-well microtiter plate was liquated with $50 \mu \mathrm{l}$ of MHB; 10th well (sterility control) was added with $100 \mu \mathrm{l}$ of MHB. And the 9th well (growth control) was added with MHB with 5\% DMSO. $50 \mu \mathrm{l}$ of each extract initially dissolved in 5\% DMSO was added into the first well. A serial 2-fold dilution was performed by transferring suspension to the subsequent wells up till the 8th well; this procedure was performed by CLSI guideline and modifying Wiegand protocol [25]. 0.5 McFarland broth inoculum was diluted in the ratio of 1 : 100 and added into 1st- 8th well in achieving the final inoculum size at $5 \times 10^{5} \mathrm{CFU} / \mathrm{ml}$ [28].

Bacterial cell viability and MIC values were determined by observing the turbidity. The lowest concentration of the extract with clear suspension was considered as the MIC values. The lowest concentration of the extract in the post-incubation suspensions which did not harbor any bacterial growth upon spotting on MHA after overnight incubation at $37^{\circ} \mathrm{C}$ were considered as the $\mathrm{MBC}$ values. The test was performed in triplicates alongside antibiotics ciprofloxacin $(5 \mu \mathrm{g})$ as a positive control at $0.1 \mathrm{mg} / \mathrm{ml}[27,28]$. MIC values were determined by observing the turbidity. The lowest concentration of the extract with clear suspension was considered as the MIC values. The lowest concentration of the extract in the post-incubation suspensions which did not harbor any bacterial growth upon spotting on MHA after overnight incubation at $37^{\circ} \mathrm{C}$ were considered as the $\mathrm{MBC}$ values. The same method as for bacterial tests was adopted for fungi. However, instead of nutrient agar, sabouraud dextrose agar was used. The inoculated medium was incubated at $37^{\circ} \mathrm{C}$ for $\mathrm{C}$. albicans. The test was performed in triplicates alongside antibiotics ciprofloxacin $(5 \mu \mathrm{g})$ as a positive control at a concentration of $0.1 \mathrm{mg} / \mathrm{ml}$ for bacteria; whereas, ketoconazole was used as a positive control at a concentration of $0.3 \mathrm{mg} / \mathrm{ml}$ for fungi $[13,31,32]$.

\section{Phytochemical screening}

The presence of the major phytochemical constituents was identified as alkaloids, flavonoids, saponins, phenolic, tannins, terpenoid, and cardiac glycosides in $80 \%$ methanol extracts of each plant using modified standard procedures as mentioned our previous work [13, 33].

\section{Statistical analysis}

The triplicate data were reading values of inhibition zones in diameter and concentration values (MIC \& $\mathrm{MBC}$ ) analyzed using SPSS, version 21 according to CLSI. Each experiment values were expressed as mean \pm SD. Statistical significance was determined by student's T-test. Values with $p<0.05$ were considered significance.

\section{Results}

\section{Phytochemical screening of medicinal plants}

This study revealed that air dried powder form of each medicinal plants has varies yield in $80 \%$ methanol extraction. The highest yield was observed for C. englerianum (38\%) which used to treat gonorrhea, tonsillitis, syphilis, wound amebiasis, malaria, and diarrhea by pastoralist community. However, the lowest yield was observed for E. depauperata (22\%) which was mainly used to treat skin rash, ringworm, bloody diarrhea, gastritis, and constipation (Table 1). On the other hand, the qualitative phytochemical investigation showed that these tested medicinal plants have different phytochemicals namely; saponins, tannins, alkaloids, terpenoids, anthraquinones, phenolics, cardiac glycosides and flavonoids (Table 2). Thus, naturally occurring bioactive attribute significant bactericidal action on ( $E$. coli, K. pneumoniae, S. aureus, and E. faecalis) and fungicidal (C. albicans) properties.

\section{Antibacterial effect of extracts on multidrug resistant bacteria}

Almost all extracts showed antibacterial activity against two or more of the multidrug resistant and reference strains of human pathogenic bacteria. The extract of $E$. depauperata, $R$. abyssinicus and L. adoensis showed promising antibacterial activity as they inhibited the growth of K. pneumoniae, S. aureus and E. faecalis with zone of inhibition ranging $21-27 \mathrm{~mm}$ at their $30 \mu \mathrm{l} /$ disc. The methanolic extract of C. englerianum, L. adoensis 
Table 1 Ethno-botanical data and percentage yields of medicinal plants tested on pathogenic microbial

\begin{tabular}{|c|c|c|c|c|c|}
\hline $\begin{array}{l}\text { Scientific } \\
\text { name }\end{array}$ & Family & $\begin{array}{l}\text { Local } \\
\text { name }\end{array}$ & $\begin{array}{l}\text { Part } \\
\text { used }\end{array}$ & $\begin{array}{l}\% \text { yield } \\
\text { (mean } \pm \\
\text { SD) }\end{array}$ & Locally used to treat \\
\hline $\begin{array}{l}\text { Cirsium } \\
\text { englerianum }\end{array}$ & Asteraceae & Adaddoo & Leaf & $38.1 \pm 1.0$ & Gonorrhea, UTI, tonsillitis, syphilis, wound amebiasis, malaria, diarrhea \\
\hline $\begin{array}{l}\text { Euphorbia } \\
\text { depauperata }\end{array}$ & Euphorbiaceae & Gurii & Bark & $22.3 \pm 0.9$ & Skin rash, ringworm, bloody diarrhea, UTI, gastritis, constipation \\
\hline Lippia adoensis & Verbenaceae & Urgoo & Leaf & $27.3 \pm 1.7$ & Stomach ache, kidney disease, diarrhea, wound and cough \\
\hline $\begin{array}{l}\text { Discopodium } \\
\text { penninervium }\end{array}$ & Solanaceae & Maraaro & Leaf & $33.9 \pm 0.4$ & Eczema, wound, scabies, urine retention \\
\hline $\begin{array}{l}\text { Cucumis } \\
\text { pustulatus }\end{array}$ & Cucurbitaceae & Haadhatu & Root & $29.1 \pm 2.8$ & Cough, TB and chest pain, cold disease, Pneumonia \\
\hline $\begin{array}{l}\text { Rumex } \\
\text { abyssinicus }\end{array}$ & Polygonaceae & Dhangagoo & Root & $24.0 \pm 0.3$ & $\begin{array}{l}\text { Gonorrhea, skin diseases, diarrhea, abscesses, ringworm, pain-relieving, diuretic ef- } \\
\text { fect, hypertension, anti-cancer, malaria, wound healing }\end{array}$ \\
\hline
\end{tabular}

and $E$. depauperata showed inhibition zone of $25 \mathrm{~mm}$, $22 \mathrm{~mm}$ and $23 \mathrm{~mm}$ in diameter against MRSA respectively. Of gram-positive bacteria, E. faecalis was highly susceptible for methanolic extract of $C$. englerianum. This extract inhibited the growth of both drug resistant and susceptible strains with $27 \mathrm{~mm}$ inhibition zone. Moreover, the effectiveness of tested extract had MIC value of gram-positive bacteria ranging $1.0-64.0 \mu \mathrm{g} / \mathrm{ml}$. In this regard, $C$. englerianum showed bactericidal in the low dose on $E$. faecalis with $\mathrm{MIC}$ and $\mathrm{MBC}$ values $1.0 \mu \mathrm{g} / \mathrm{ml}$ and $2.0 \mu \mathrm{g} / \mathrm{ml}$ respectively. Likewise, it inhibited the growth of $S$. aureus with $24 \mathrm{~mm}$ inhibition zone, $\mathrm{MIC}$ and $\mathrm{MBC}$ values were $16 \mu \mathrm{g} / \mathrm{ml}$ and $32.0 \mu \mathrm{g} / \mathrm{ml} \mathrm{re}-$ spectively (Table 4).

The methanolic extract of $E$. depauperata had strong antibacterial activity on MSSA and MRSA with inhibition zone of $23 \mathrm{~mm}$ (Table 3 ). This plant extract exhibited remarkable inhibition of the growth of MRSA with MIC and $\mathrm{MBC}$ values ranging from 4.0-8.0 $\mu \mathrm{g} / \mathrm{ml}$ (Table 4).
This study revealed that E. depauperata, C. engleria$n u m$ and $D$. penninervium inhibited the growth of $E$. coli and K.pneumoniae that attributed for $85 \%$ urinary tract infections. In line of this, those medicinal plants inhibited the growth of multidrug resistant $K$. pneumoniae ranging 11-27 $\mathrm{mm}$ in diameter. Of which, L.adoensis and D. penninervium are demonstrated promising treatment for multidrug resistant K.pneumoniae with $27 \mathrm{~mm}$ and $26 \mathrm{~mm}$ inhibition zone respectively (Table 3 ). On the other hand, E. depauperata, C. englerianum and D. penninervium demonstrated on the multidrug resistant $E$. coli with $12 \mathrm{~mm}, 21 \mathrm{~mm}$ and $23 \mathrm{~mm}$ inhibition zones in diameter respectively (Table 3 ). The second most susceptible bacteria were clinical isolates of multidrug resistant and reference strain of $K$. pneumoniae with MIC and $\mathrm{MBC}$ value ranging from $2.0-16.0 \mu \mathrm{g} / \mathrm{ml}$ and $2.0-$ $32.0 \mu \mathrm{g} / \mathrm{ml}$ respectively (Table 4 ).

Overall, those medicinal plants have bioactive that able to bactericidal property and used as alternative and/or

Table 2 Preliminary phytochemical screening of some traditional medicinal plants, KMU, 2020

\begin{tabular}{|c|c|c|c|c|c|c|c|c|c|}
\hline \multirow{2}{*}{$\begin{array}{l}\text { Scientific name } \\
\text { (parts) }\end{array}$} & \multirow{2}{*}{$\begin{array}{l}\text { Solvent } \\
\text { used }\end{array}$} & \multicolumn{8}{|c|}{ Major phytochemicals in crude extract of medicinal plants } \\
\hline & & Saponin & Tannins & Alkaloids & Terpenoids & Anthraquinone & Flavonoids & Phenolic & Cardiac glycoside \\
\hline \multirow[t]{2}{*}{ C. englerianum (fruit) } & Methanol & + & ++ & +++ & + & + & +++ & +++ & ++ \\
\hline & Aqueous & - & ++ & ++ & + & - & + & +++ & ++ \\
\hline \multirow{2}{*}{$\begin{array}{l}\text { E. depauperata } \\
\text { (Bark) }\end{array}$} & Methanol & +++ & - & ++ & + & + & +++ & + & + \\
\hline & Aqueous & ++ & - & + & - & ++ & ++ & ++ & - \\
\hline \multirow{2}{*}{$\begin{array}{l}\text { L. adoensis } \\
\text { (Leaf) }\end{array}$} & Methanol & ++ & + & +++ & + & +++ & ++ & + & - \\
\hline & Aqueous & - & + & + & - & + & ++ & + & + \\
\hline \multirow{2}{*}{$\begin{array}{l}\text { D.penninervium } \\
\text { (Leaf) }\end{array}$} & Methanol & +++ & + & +++ & + & ++ & +++ & - & ++ \\
\hline & Aqueous & + & +++ & ++ & + & ++ & + & - & + \\
\hline \multirow{2}{*}{$\begin{array}{l}\text { C. pustulatus } \\
\text { (Root) }\end{array}$} & Methanol & + & ++ & - & - & ++ & + & ++ & + \\
\hline & Aqueous & + & - & - & + & + & + & + & ++ \\
\hline \multirow{2}{*}{$\begin{array}{l}\text { R. abyssinicus } \\
\text { (Root) }\end{array}$} & Methanol & ++ & + & + & ++ & +++ & + & ++ & - \\
\hline & Aqueous & +++ & + & ++ & + & ++ & - & ++ & + \\
\hline
\end{tabular}


Table 3 Inhibition zone in diameter of pathogenic microbes on agar disc diffusion, KMU, 2020

\begin{tabular}{|c|c|c|c|c|c|c|c|c|c|c|c|c|}
\hline \multirow{4}{*}{$\begin{array}{l}\text { Scientific } \\
\text { name }\end{array}$} & \multicolumn{2}{|c|}{ Concentration } & \multicolumn{10}{|c|}{ Inhibition zone in diameter $(\mathrm{mm})$} \\
\hline & & & \multicolumn{4}{|c|}{ Gram positive bacteria } & \multicolumn{4}{|c|}{ Gram negative bacteria } & \multirow{2}{*}{\multicolumn{2}{|c|}{$\begin{array}{l}\text { Fungi } \\
\text { C. albicans }\end{array}$}} \\
\hline & & & \multicolumn{2}{|l|}{ S. aureus } & \multicolumn{2}{|c|}{ E. faecalis } & \multicolumn{2}{|l|}{ E.coli } & \multicolumn{2}{|c|}{ K. pneumoniae } & & \\
\hline & $\mathrm{Mg} / \mathrm{ml}$ & $\mu \mathrm{l} / \mathrm{disc}$ & ATCC & MRSA & ATCC & MDR & ATCC & MDR & ATCC & MDR & ATCC & Sample \\
\hline \multirow[t]{2}{*}{ C. englerianum } & 100 & 15 & $16 \pm .0 .1$ & $15 \pm 0.4$ & $18 \pm 0.9$ & $17 \pm 1.0$ & $9 \pm 0.3$ & $13 \pm 1.4$ & $16 \pm 2.0$ & $11 \pm 0.1$ & $14 \pm 1.1$ & - \\
\hline & & 30 & $24 \pm 3.0$ & $25 \pm 0.8^{* *}$ & $27 \pm 1.3$ & $27 \pm 1.5^{\#}$ & $20 \pm 0.7$ & $21 \pm 0.2$ & $26 \pm 0.8$ & $26 \pm 0.9^{¥}$ & $21 \pm 0.7$ & $9 \pm 0.3$ \\
\hline \multirow[t]{2}{*}{ E. depauperata } & 100 & 15 & $15 \pm .0 .6$ & $14 \pm 0.7$ & $16 \pm 2.0$ & $17 \pm 0.3$ & - & - & $17 \pm 0.1$ & $18 \pm 0.7$ & - & $10 \pm 0.9$ \\
\hline & & 30 & $23 \pm 2.4$ & $23 \pm 1.0^{*}$ & $26 \pm 0.9$ & $26 \pm 0.5^{\#}$ & $13 \pm 0.1$ & $12 \pm 0.4$ & $25 \pm 1.2$ & $25 \pm 0.7^{¥}$ & $22 \pm 1.1$ & $23 \pm 0.7$ \\
\hline \multirow[t]{2}{*}{ L. adoensis } & 100 & 15 & $16 \pm .1 .2$ & $12 \pm 0.1$ & $11 \pm 1.1$ & $14 \pm 0.1$ & $10 \pm 0.7$ & $14 \pm 0.2$ & $20 \pm 0.6$ & $20 \pm 0.3$ & - & $9 \pm 0.3$ \\
\hline & & 30 & $22 \pm 2.4$ & $21 \pm 1.8$ & $21 \pm 0.5$ & $21 \pm 1.5$ & $21 \pm 2.1$ & $21 \pm 0.3$ & $27 \pm 0.1$ & $27 \pm 0.7^{¥}$ & $11 \pm 0.9$ & $20 \pm 0.1$ \\
\hline \multirow[t]{2}{*}{ D.penninervi m } & 100 & 15 & $16 \pm .0 .3$ & $14 \pm 0.1$ & $16 \pm 0.4$ & $15 \pm 0.7$ & $20 \pm 0.7$ & $19 \pm 1.0$ & $18 \pm 0.3$ & $16 \pm 0.2$ & $13 \pm 0.3$ & $9 \pm 1.6$ \\
\hline & & 30 & $21 \pm 0.5$ & $23 \pm 2.0^{*}$ & $21 \pm 0.1$ & $20 \pm 1.0$ & $25 \pm 0.8$ & $23 \pm 0.1$ & $23 \pm 0.7$ & $21 \pm 0.4$ & $20 \pm 0.9$ & $19 \pm 0.4$ \\
\hline \multirow[t]{2}{*}{ R. abyssinicus } & 100 & 15 & $14 \pm 0.9$ & $9 \pm 0.8$ & $15 \pm 1.1$ & $11 \pm 1.0$ & - & - & $11 \pm 1.0$ & $9 \pm 0.7$ & $10 \pm 0.2$ & $14 \pm 0.4$ \\
\hline & & 30 & $22 \pm 0.6$ & $20 \pm 0.4$ & $25 \pm 0.4$ & $19 \pm 1.1$ & $10 \pm 0.8$ & $12 \pm 0.1$ & $20 \pm 0.1$ & $19 \pm 0.6$ & $21 \pm 0.5$ & $21 \pm 0.1$ \\
\hline \multirow[t]{2}{*}{ C. pustulatus } & 100 & 15 & $12 \pm 1.0$ & $12 \pm 0.2$ & $12 \pm 0.8$ & $16 \pm 1.2$ & $15 \pm 0.2$ & $10 \pm 0.8$ & $10 \pm 0.9$ & $11 \pm 0.8$ & $12 \pm 0.8$ & $10 \pm 0.1$ \\
\hline & & 30 & $21 \pm 0.8$ & $21 \pm 0.8$ & $23 \pm 0.5$ & $22 \pm 0.8^{\#}$ & $23 \pm 0.4$ & $18 \pm 0.9$ & $21 \pm 1.0$ & $21 \pm 0.4$ & $18 \pm 0.1$ & $18 \pm 0.8$ \\
\hline Modern drug & & & $22 \pm 2.0^{\mathrm{Ce}}$ & $12 \pm 1.9^{\mathrm{Ce}}$ & $22 \pm 3.0^{c}$ & $13 \pm 1.2^{c}$ & $26 \pm 2.1^{C}$ & $15 \pm 2.3^{C}$ & $24 \pm 1.2^{c}$ & $14 \pm 1.9^{C}$ & $22 \pm 0.3^{F}$ & $21 \pm 1.3^{\mathrm{F}}$ \\
\hline
\end{tabular}

Mean $\pm S D, N T$ Not tested, $-=$ No inhibition zone, C Ciprofloxacin, Ce Cefoxitin, $F$ Ketoconazole, $M D R<16 \mathrm{~mm}, A T C C>21 \mathrm{~mm} * P<0.05, * * P<0.01$ compared to cefoxitin treated MRSA. ${ }^{\# P}<0.05$ compared to modern drug treated $E$. faecalis, ${ }^{*} P<0.05$ compared to modern drug treated $K$. pneumoniae

complementary treatment for urinary tract infection. This is illustrated by minimum bactericidal concentration as parallel tested with modern antibiotics. As a result, thoroughly exploited traditional medicinal plants is the way to overcome health consequence of drug resistance bacteria caused human and animals' ailments in general and urinary tract infections in particular.

\section{Antifungal activity of medicinal plants}

This study revealed that methanolic extracts obtained from C. englerianum, $L$. adoensis, D. penninervium and $R$. abyssinicus demonstrating remarkable anti-fungal effect against $C$. albicans (Table 3). Of which, $R$. abyssinicus showed promising antifungal effect as compared to others. It had $21 \mathrm{~mm}$ inhibition zone in diameter and

Table 4 MIC and MBC/MFC values of methanolic extract against pathogenic microbes, KMU, 2020

\begin{tabular}{|c|c|c|c|c|c|c|c|c|c|c|c|}
\hline \multirow{4}{*}{$\begin{array}{l}\text { Scientific } \\
\text { name }\end{array}$} & \multirow{4}{*}{$\begin{array}{l}\text { MIC/ } \\
\text { MBCMFC }\end{array}$} & \multicolumn{10}{|c|}{ Concentration of extracts in $\mu \mathrm{g} / \mathrm{ml}$ on pathogen bacteria and fungi } \\
\hline & & \multicolumn{4}{|c|}{ Gram positive bacteria } & \multicolumn{4}{|c|}{ Gram negative bacteria } & \multirow{2}{*}{\multicolumn{2}{|c|}{$\begin{array}{l}\text { Fungi } \\
\text { C. albicans }\end{array}$}} \\
\hline & & \multicolumn{2}{|c|}{ S. aureus } & \multicolumn{2}{|c|}{ E. faecalis } & \multicolumn{2}{|l|}{ E.coli } & \multicolumn{2}{|c|}{ K. pneumoniae } & & \\
\hline & & $\overline{\text { ATCC }}$ & $\overline{\text { MRSA }}$ & $\overline{\text { ATCC }}$ & $\overline{M D R}$ & ATCC & $\overline{M D R}$ & $\overline{\text { ATCC }}$ & MDR & $\overline{\text { ATCC }}$ & Sample \\
\hline \multirow[t]{2}{*}{ C.englerianum } & MIC & 16.0 & 16.0 & 1.0 & 1.0 & 64.0 & 64.0 & 2.0 & 2.0 & 128.0 & 64.0 \\
\hline & $\mathrm{MBC} / \mathrm{MFC}$ & 32.0 & 32.0 & 2.0 & 2.0 & 128.0 & 128.0 & 2.0 & 2.0 & 128.0 & 128.0 \\
\hline \multirow[t]{2}{*}{ E. depauperata } & MIC & 4.0 & 4.0 & 4.0 & 4.0 & 128.0 & 128.0 & 16.0 & 16.0 & NT & 64.0 \\
\hline & $\mathrm{MBC} / \mathrm{MFC}$ & 4.0 & 8.0 & 8.0 & 8.0 & 128.0 & 128.0 & 16.0 & 16.0 & NT & 128.0 \\
\hline \multirow[t]{2}{*}{ L. adoensis } & MIC & 64.0 & 32.0 & 16.0 & 16.0 & 64.0 & 64.0 & 16.0 & 16.0 & 384.0 & 512.0 \\
\hline & $\mathrm{MBC} / \mathrm{MFC}$ & 128.0 & 128.0 & 16.0 & 16.0 & 64.0 & 64.0 & 32.0 & 32.0 & NT & NT \\
\hline \multirow[t]{2}{*}{ D. penninervium } & MIC & 8.0 & 8.0 & 8.0 & 16.0 & 16.0 & 16.0 & 16.0 & 16.0 & 128.0 & 128.0 \\
\hline & $\mathrm{MBC} / \mathrm{MFC}$ & 16.0 & 16.0 & 8.0 & 8.0 & 16.0 & 16.0 & 32.0 & 32.0 & 128.0 & 128.0 \\
\hline \multirow[t]{2}{*}{ R. abyssinicus } & MIC & 16.0 & 16.0 & 64.0 & 64.0 & 128.0 & 128.0 & 16.0 & 16.0 & 32.0 & 16.0 \\
\hline & $\mathrm{MBC} / \mathrm{MFC}$ & 32.0 & 16.0 & 128.0 & 128.0 & 64.0 & 64.0 & 32.0 & 16.0 & 64.0 & 32.0 \\
\hline \multirow[t]{2}{*}{ C. pustulatus } & MIC & 64.0 & 64.0 & 4.0 & 4.0 & 32.0 & 32.0 & 8.0 & 8.0 & 128.0 & 256.0 \\
\hline & $\mathrm{MBC} / \mathrm{MFC}$ & 64.0 & 64.0 & 8.0 & 8.0 & 64.0 & 64.0 & 16.0 & 16.0 & 128.0 & NT \\
\hline Modern drug & & $0.1^{\mathrm{Ce}}$ & ++ & $0.1^{C}$ & ++ & $0.1^{c}$ & ++ & $0.1^{c}$ & ++ & $0.3^{F}$ & $0.3^{F}$ \\
\hline
\end{tabular}


MIC values ranging from 16 to $32 \mu \mathrm{g} / \mathrm{ml}$. In addition, extracts of $D$. penninervium and $C$. englerianum showed inhibitory activity against fungi with MIC/MFC values ranging $16-512 \mu \mathrm{g} / \mathrm{ml}$, whereas those of $L$. adoensis was found to be less potent for $C$. albicans with MIC ranging $512 \mu \mathrm{g} / \mathrm{ml}$.

\section{Discussion}

Nowadays, majority of the cases from urinary tract infections caused by multidrug resistance microbes constitutes an important therapeutic challenge. They are widely spread and public health concern at global scale worldwide. Resistance mechanism developed by MDR microbes are transfer from one strain to another bacteria through efflux, hyper-mutability and plasmid addiction. As a result, urinary tract infections caused with MRSA, extended-spectrum $\beta$-lactamases producing organisms (ESBL), vancomycin-resistant enterococci (VRE), and the carbapenem-resistant organisms (CRE/CRP) have higher morbidity and mortality. They are costlier to treat, result in longer hospital stays and place a greater burden on health systems than infections caused by susceptible organisms. These multidrug resistant microbes have compromised all or majority of currently accessible and affordable antibiotics widely used in the developing countries. In such case, searching for antibiotic from natural resources in general and medicinal plants in particular is timely concern. Those plants have wide application in the treatment of urinary tract infections caused by multidrug resistant bacteria and fungi. This can be demonstrated in that almost all tested medicinal plants had shown promising antimicrobial activity against the selected human pathogenic microbes. This finding substantiates from previous studies that therapeutic agents derived from plants can be used as an important alternative for the treatment of infectious disease [9-12].

This study revealed that all species of the plants used here had antibacterial activity and also indicated that $E$. faecalis was the most susceptible species of all tested human pathogenic bacteria. Moreover, most of the extracts have shown remarkable inhibitory effect on MRSA. Likewise, multidrug resistant and its reference strains of $K$. pnemoniae were found to be the most sensitive gramnegative bacteria against the tested plant extracts. Implausibly, both multidrug resistant and reference strains of $E$. coli were the most unresponsive strain of all tested bacteria species. These findings agreed with several reports $[13,19-21]$ which demonstrated that gram positive (S. aureus and E. faecalis) bacteria to be more sensitive than gram negative (E. coli and $K$. pneumonia) bacteria for the plants' phytochemical components being studied. Moreover, many studies have shown that medicinal plants contain different bioactive ingredients that inhibited the growth of human pathogenic bacteria [22]. On the other hand, researchers demonstrated that E. coli has developed multidrug resistance to many currently available and affordable antibiotics [3, 23]. Thus, genetic makeup to $E$. coli to produce multidrug resistance was favorable to impede the antibiotics through reduced permeability and efflux pump $[6,23,26]$. As a result, searching for antibacterial activity of the secondary metabolites from medicinal plants is a timely concern [1214]. In this regard, medicinal plants can be used to overcome socioeconomic and health impact caused by multidrug resistant bacteria, including MRSA and multidrug resistant gram-negative bacteria such as $E$. coli and $K$. pneumoniae [12-14].

Regarding the human pathogen fungi, the presence of bioactive compounds in traditional medicinal plants could inhibit the growth of $C$. albicans. A study done by Shumaia Parvin shown that C. gigantean had inhibitory potential on all tested human pathogenic bacteria and fungi except $T$. rubrum [16]. Another study conducted on extracts of Carum copticum and Albizia adianthifolia had exhibited good antimicrobial activities against $E$. coli, Proteus species, P. aeruginosa, P. neumoniae and Salmonellae species $[18,19]$.

Overall, this study showed that among the tested human pathogenic microbes, fungi were found to be more unaffected by many of the tested extracts than bacteria. These findings demonstrated that C. albicans was less susceptible than those tested pathogen bacteria. The presence of different bioactive constituents can inhibit the growth of not only multidrug resistant bacteria but also inhibit growth of fungi. This difference in effect on the growth of $C$. albicans indicate the presence of antifungal constituents in the crude extracts of each plant. This agrees with previous findings on the antifungal activity of medicinal plants containing different secondary metabolites that inhibited pathogen fungi $[16,17,27]$.

We can affirm that our preliminary findings suggest most endemic medicinal plants contain flavonoid, anthraquinones, alkaloids, tannin, phenolic and saponin (Table 2). The presence of these bioactive ingredients can inhibit the growth of not only reference strains but also multidrug resistant microbes. In this regard, many studies demonstrated that medicinal plants contain coumarins, flavonoids, phenolic, alkaloids, terpenoids, tannins and polyacetylenes which can be bactericidal, bacteriostatic or produce fungicidal effect on human pathogenic microbes $[11,13,29]$. Other researchers proposed that this inhibitory activity of secondary metabolites may be due to sequential inhibition of biochemical pathways, inhibition of protein synthesis and disintegration of the outer membrane of the microbes [20, 24]. In line with this, many researchers argued that medicinal plants contain diversified secondary metabolites and this makes them a possible alternative for treating infections 
caused by microbes including multidrug resistant microbes $[13,14,17,28]$. Therefore, a lot has to be done to explore the potential of such medicinal plants as a possible source of antimicrobials that can be used against multidrug resistant bacteria and fungi.

\section{Conclusions}

Those of tested medicinal plants were found to have more antibacterial effect than antifungal activity. They showed promising antimicrobial effect on multidrug resistant bacteria. Hence, identification and isolation of secondary metabolites from those medicinal plants will help pharmaceutical companies to develop modulator or precursor for the synthesis of new novel antibiotics used to treat diseases caused by pathogens including multidrug resistant bacteria.

\section{Abbreviations}

ATCC: American type culture collection used as reference strains; CLSI: Clinical laboratory standard institute; ESBL: Extended spectrum beta lactamase; MBC: Minimum bactericidal concentration; MDR: Multi drug resistant; MHA: Muller hinton agar; MHB: Muller hinton broth; MRSA: Methicillin resistant Staphylococcus aureus; MSSA: Methicillin susceptible Staphylococcus aureus; MBC: Minimal bactericidal concentration; MIC: Minimal inhibitory concentration; TMP: Traditional medicinal plants

\section{Acknowledgements}

We would like to acknowledge KMU for financial support of this research project. We would like to also extend our gratitude to administration and staff members of Seweyna Woreda, and Bale Zone. Medical Laboratory Department of MMHSC allowed us to use their laboratory facilities. We would like to thank Taxonomist Dr. Melaku Wondafrash for identifying plant samples at National Herbarium of AAU.

Last, but not least, our special thanks go to Mr. Tufa Seboke, Mrs. Simegne Terefe, Mr. Shafi Mohammed, Mr. Kasim Kedir, Mr. Mequanint Mitiku, Mr. Sultan Mohammed, Mrs. Kemeru Waliy, S/r Nigatua Desta and Mr. Deme Birhanu for their respective support during plant collection and unreserved encouragement during the conduct of this research project.

\section{Authors' contributions}

EG and ET were equally contributed for designing, performing the laboratory work on MIC and MBC, participated in the extraction, susceptibility testing and analysis of data. All authors read and approved the final manuscript.

\section{Funding}

This research has been funded by Kotebe Metropolitan University for data collections, laboratory reagents and other costs. The University had no role in study design, in the writing of the report; and in the decision to submit the article for publication.

\section{Availability of data and materials}

All data and materials of this work are available from the corresponding author on request.

\section{Ethics approval and consent to participate}

This study was conducted after it is ethically reviewed and approved by the Research and Ethical Review Committee of Department of Medical Laboratory Science, College of Health Sciences, Kotebe Metropolitan University.

\section{Consent for publication}

Not applicable.

\section{Competing interests}

The authors have declared that, they have no competing interests.

\section{Author details}

${ }^{1}$ Department of Medical Laboratory Science, Menelik Medical and Health Science College, Kotebe Metropolitan University, P.O. Box 3268, Addis Ababa, Ethiopia. ${ }^{2}$ Department of Nutrition Science, MMHSC, KMU, Addis Ababa, Ethiopia.

Received: 19 September 2020 Accepted: 15 February 2021

Published online: 23 February 2021

\section{References}

1. Fair RJ, Tor Y. Antibiotics and bacterial resistance in the 21st century. Perspect Medicin Chem. 2014;6:25-64.

2. Lafon T, Hernandez Padilla AC, Baisse A, et al. Community-acquired S aureus bacteriuria: A warning microbiological marker for infective endocarditis. BMC Infect Dis. 2019;19:504.

3. Behzadi P, Behzadi E, Yazdanbod H, Aghapour R, Akbari Cheshmeh M, Salehian OD. Urinary tract infections associated with C. albicans. Maedica. 2010;5(4):277-9.

4. Heintz BH, Halilovic J, Christensen CL. Vancomycin-resistant enterococcal urinary tract infections. Pharmacotherapy. 2010;30(11):1136-49.

5. Ludden C, Cormican M, Vellinga A, Johnson JR, Austin B, Morris D. Colonization with ESBL-producing and carbapenemase-producing Enterobacteriaceae, vancomycin-resistant enterococci, and MRSA in a longterm care facility over one year. BMC Infect Dis. 2015;15:168.

6. Shriram V, Khare T, Bhagwat R, Shukla R, Kumar V. Inhibiting bacterial drug efflux pumps via phyto-therapeutics tocombat threatening antimicrobial resistance. Front Microbiol. 2018;9:2990,

7. Frost I, Van Boeckel TP, Pires J, Craig J, Laxminarayan R. Global geographic trends in antimicrobial resistance: the role of international travel. J Travel Med. 2019;26(8):taz036.

8. Prestinaci F, Pezzotti P, Pantosti A. Antimicrobial resistance: a global multifaceted phenomenon. Pathog Glob Health. 2015;109(7):309-18.

9. Dadgostar P. Antimicrobial resistance: implications and costs. Infect Drug Resist. 2019;12:3903-310.

10. Brown $\mathrm{E}$, Wright $\mathrm{G}$. Antibacterial drug discovery in the resistance era. Nature. 2016;529:336-43.

11. WHO. Global report on traditional and complementary medicine 2019. Geneva: World Health Organization; 2019. Licence: CC BY-NC-SA 3.0 IGO

12. Rossiter SE, Fletcher MH, Wuest WM. Natural products as platforms to overcome antibiotic resistance. Chem Rev. 2017;117(19):12415-74.

13. Gadisa E, Weldearegay G, Desta K, et al. Combined antibacterial effect of essential oils from three most commonly used Ethiopian traditional medicinal plants on multidrug resistant bacteria. BMC Complement Altern Med. 2019;19(1):24.

14. Khameneh $B$, Iranshahy $M$, Soheili $V$, et al. Review on plant antimicrobials: a mechanistic viewpoint. Antimicrob Resist Infect Control. 2019;8:118.

15. Liu HY, Lin HC, Lin YC, Yu SH, Wu WH, Lee YJ. Antimicrobial susceptibilities of urinary extended-spectrum beta-lactamase-producing $E$. coli and $K$. pneumoniae to fosfomycin and nitrofurantoin in a teaching hospital in Taiwan. J Microbiol Immunol Infect. 2011;44(5):364-8.

16. Shumaia P, Abdul K, Aktar C, Ekramul H. Antibacterial, antifungal and insecticidal activities of the $n$-hexane and ethyl-acetate fractions of methanolic extract of the leaves of Calotropis gigantea. JPP. 2014;2(5):47-51.

17. Ohikhena FU, Wintola OA, Afolayan AJ. Evaluation of the antibacterial and antifungal properties of Phragmanthera capitata (Sprengel) Balle (Loranthaceae), a mistletoe growing on rubber tree, using the dilution techniques. Sci World J. 2017;2017:9658598.

18. Maheshwari M, Safar Althubiani A, Hasan Abulreesh H, Abul Qais F, Shavez Khan M, Ahmad I. Bioactive extracts of Carum copticum enhances efficacy of ciprofloxacin against MDR enteric bacteria. Saudi J Biol Sci. 2019;26:1848-55.

19. Tchinda CF, Sonfack G, Simo IK, et al. Antibacterial and antibiotic-modifying activities of fractions and compounds from Albizia adianthifolia against MDR gram-negative enteric bacteria. BMC Complement Altern Med. 2019;19(1):120.

20. Tayel AA, Shaban SM, Moussa SH, Elguindy NM, Diab AM, Mazrou KE, ElSabbagh SM. Bioactivity and application of plant seeds' extracts to fight resistant strains of S. aureus. Ann Agric Sci. 2018;63(1):47-53.

21. Marathe NP, Rasane MH, Kumar H, Patwardhan AA, Shouche YS, Diwanay SS. In vitro antibacterial activity of Tabernaemontana alternifolia stem bark aqueous extracts against clinical isolates of methicillin resistant $S$ aureus. Ann Clin Microbiol Antimicrob. 2013;12:26. 
22. Saeidi S, Amini Boroujeni N, Ahmadi H, Hassanshahian M. Antibacterial activity of some plant extracts against extended-spectrum beta-lactamase producing E. coli isolates. Jundishapur J Microbiol. 2015;8(2):e15434.

23. Terlizzi ME, Gribaudo G, Maffei ME. Uropathogenic E.coli infections: Virulence factors, bladder responses, antibiotic, and non-antibiotic antimicrobial strategies. Front Microbiol. 2017;8:1566.

24. Chuah EL, Zakaria ZA, Suhaili Z, Abu Bakar S, MNM D. Antimicrobial activities of plant extracts against MSSA and methicillin-Resistant S. aureus. Int J Microbiol Res. 2014;4(1):6-13.

25. Gonzalez-Alamilla EN, Gonzalez-Cortazar M, Valladares B, et al. Chemical constituents os Salix babylonica and their antibacterial activity against gram positive and gram negative animal bacteria. Molecules. 2019;24(16):2992

26. Aris $\mathrm{P}$, Boroumand MA, Rahbar M, Douraghi $\mathrm{M}$. The activity of fosfomycin against extended-spectrum beta-lactamase-producing isolates of Enterobacteriaceae recovered from urinary tract infections: a single-center study over a period of 12 years. Microb Drug Resist. 2018;24(5):607-12.

27. Salam AM, Quave CL. Opportunities for plant natural products in infection control. Curr Opin Microbiol. 2018;45:189-94.

28. Varaprased B. A search for antimicrobial agents. In: Pacheco G, Alcantara C, Abreu C, Correa M, editors. Relationship between chemical structure and activity of triterpene against gram positive and gram-negative bacteria. Croatia: In Tech; 2012. p. 2-79. www.intechopen.com.

29. Atanasov AG, Waltenberger B, Pferschy-Wenzig EM, et al. Discovery and resupply of pharmacologically active plant-derived natural products: a review. Biotechnol Adv. 2015;33(8):1582-614.

30. Katiyar C, Gupta A, Kanjilal S, Katiyar S. Drug discovery from plant sources: an integrated approach. Ayu. 2012;33(1):10-9.

31. Wiegand I, Hilpert K, Hancock R. Agar and broth dilution method to determine the MIC of antimicrobial substances. Nat Protoc. 2008;3(2):163-75.

32. CLSI. Performance for antimicrobial susceptibility testing: twenty-first informational supplement-M 100-S21. Wayne, PA, USA: CLSI; 2011.

33. Abdissa D, Geleta G, Bacha K, Abdissa N. Phytochemical investigation of Aloe pulcherrima roots and evaluation for its antibacterial and antiplasmodial activities. PLoS One. 2017;12(3):e0173882.

\section{Publisher's Note}

Springer Nature remains neutral with regard to jurisdictional claims in published maps and institutional affiliations.

Ready to submit your research? Choose BMC and benefit from:

- fast, convenient online submission

- thorough peer review by experienced researchers in your field

- rapid publication on acceptance

- support for research data, including large and complex data types

- gold Open Access which fosters wider collaboration and increased citations

- maximum visibility for your research: over $100 \mathrm{M}$ website views per year

At $\mathrm{BMC}$, research is always in progress.

Learn more biomedcentral.com/submissions 